\title{
Reflection of Buber's Moral Perspective on Teacher's Professional Ethics: Teacher-Student Communication Area
}

\author{
Mohammad Ahmadgholami ${ }^{1}$, Mohammad-Hossein Heidari ${ }^{2 *}$, Hassan-Ali Bakhtiar Nasrabadi ${ }^{3}$ \\ 1. Ph.D student in philosophy of education, Department of Education, Faculty of Education and Psychology, University of Isfahan, \\ Isfahan, Iran. \\ 2. Associate Professor, Department of Education, Faculty of Education and Psychology, University of Isfahan, Isfahan, Iran. \\ 3. Professor, Department of Education, Faculty of Education and Psychology, University of Isfahan, Isfahan, Iran. \\ * Corresponding author's Email: mh.heidari@edu.ui.ac.ir
}

\begin{abstract}
Teachers in modern societies have a model, identity function, a professional and ethical mission to achieve the perfection of students. The aim of this research is to deduce guidelines for the teacher's professional ethics in the area of teacher-student communication according to the moral principles from Buber's point of view, because Buber pays special attention to the issue of ethics in human relations. The research paradigm is qualitative. The data collection method is documentary and a descriptive-interpretive approach is used to analyze the data. In order to provide guidance for each of the eight principles of teacher professional ethics, the deductive method is used. The results indicate that in the light of the unifying ability of the final moral criterion, the basic orientation of other principles of teacher's professional ethics is correctly determined. In teacher's professional ethics, Buber assigns a real position and weight to each of the poles of teacher and student; in a way, the reflection of Buber's "I-you" relationship in educational processes significantly reduces the conflicts between educational principles and the relationship between teacher and student. In the area of teacher's professional ethics, we can emphasize the positive concepts of Buber thought, which are "moral virtues".
\end{abstract}

Keywords: Martin Buber, teacher, student, relation, teacher's professional ethics.

\section{Introduction}

Since teaching has always been involved with the human factors i.e. the learner has responsibility of realizing their inherent potentials, it is generally categorized among the most sensitive professions to ethics.

In fact, teacher's professional ethics, do not have a fixed position among different branches of professional ethics. One reason could simply be the fact that teaching as a position does not have the definitiveness of a profession. This could also be attributed to the lack of an officially recognized ethical code (Haydon, 1996). Needless to say that among all human factors in an educational atmosphere, learner is the most important element on which teaching activities have direct effects. Therefore, the quality of the interaction between teacher and learner is of great significance and the relationship between them has its roots in ethical teachings.

Martin Buber (1878- 1965) a prominent Jewish and existentialist philosophers (Seif, 2006) pay a considerable attention to ethics. Unlike other existentialist thinkers who believed of the interaction between humans and world or the relation humans with with God or existence, he puts his emphasis on the interaction among humans and believed that the human will not exist beyond his interaction to other humans (Macquarie, 1998). 
Considering Buber's theory on ethical nature and professional identification of teachers on the one hand and taking social issues and contemporary education ending in ethical conflicts, self-alienation and collapsed identities of individuals into consideration (Gutek, 1997), rediscovering teacher's professional ethics based on ethical views of Buber could be of great benefits for the teacher and their interaction with their students.

In order to reach a conceptual framework on teacher's professional ethics, a proper understanding is initially required so that a proper philosophical response could be given based on ethical principles. Table 1 provides a review on the history of teacher's professional ethics.

Table 1. Principles of professional teacher's ethics based on views of prominent institutions and thinkers

\begin{tabular}{|l|l|}
\hline Institute/thinker's name & Principles of professional teacher's ethics \\
\hline $\begin{array}{l}\text { Mational Labor Union of } \\
\text { Ainistry of Education (1997) }\end{array}$ & $\begin{array}{l}\text { Observing laws, interest in the job, love for the students, seriousness in studies, } \\
\text { collaboration with colleagues, respect to parents, reliability in teaching, possessing a } \\
\text { virtuous and model personality (cited in Tan, 2006) }\end{array}$ \\
\hline $\begin{array}{l}\text { Ministry of Higher Education } \\
\text { of Malaysia (2006) }\end{array}$ & $\begin{array}{l}\text { Ethical responsibility, ethical behavior in profession, professional efficiency and } \\
\text { performance and ethical behavior toward colleagues, students, their families and the } \\
\text { society (cited in Oktay, Ramazan \& Sakin, 2010) }\end{array}$ \\
\hline Krishnaveni \& Anitha (2007) & $\begin{array}{l}\text { Analyzing ethical issues, observing ethical standards, making decisions about ethical } \\
\text { issues and ethical responsibility toward society (cited in Ngang \& Chan, 2015) }\end{array}$ \\
\hline Faramarz Gharamaleki (2010) & $\begin{array}{l}\text { knowledge, academic degree, commitment and teacher-student interaction and } \\
\text { teacher's concerns including empowerment and developing livelihood (Krishnaveni \& } \\
\text { Anitha, 2007) }\end{array}$ \\
\hline $\begin{array}{l}\text { Ultimate value criterion, table of vices and virtues, analyzing objective ethical } \\
\text { problems, expressing professional ethical issues, settling ethical conflicts, preventing } \\
\text { ethical problems, correcting behavior, elevating personality and self and moral model } \\
\text { (Faramarz Gharamaleki, 2010) }\end{array}$ \\
\hline
\end{tabular}

In order to make a deduction on teacher's professional ethics, it should be noted that the principles listed by Faramarz Gharamaleki (2010) seem to be more comprehensive. Table 2 gives a systematic definition of teacher's professional ethics.

Table 2. Principles of teacher's professional ethics

\begin{tabular}{|l|l|l|}
\hline No. & Main Title & Definition of Principle \\
\hline 1 & Presenting ultimate ethical criterion & $\begin{array}{l}\text { In teacher's professional ethics, the ultimate ethical criterion is determined } \\
\text { according to an ethical theory. }\end{array}$ \\
\hline 2 & Elaborating moral vices and virtues & $\begin{array}{l}\text { Teacher's professional ethics has to provide a list of desirable and } \\
\text { undesirable ethical behaviors. }\end{array}$ \\
\hline 3 & $\begin{array}{l}\text { Analyzing the encounter with } \\
\text { objective ethical issues in } \\
\text { professional activities }\end{array}$ & $\begin{array}{l}\text { Teacher's professional ethics has to create a framework for analyzing } \\
\text { objective ethical issues so that ethical responsibility of teachers encountering } \\
\text { ethical and professional dilemmas is defined. }\end{array}$ \\
\hline 4 & $\begin{array}{l}\text { Settling ethical dilemmas } \\
5\end{array}$ & $\begin{array}{l}\text { Modification and correction of } \\
\text { to be clearly defined. }\end{array}$ \\
\hline 6 & $\begin{array}{l}\text { lf purification and personality } \\
\text { excellence }\end{array}$ & $\begin{array}{l}\text { It is expected to present procedures to correct moral vices. } \\
\text { souls and realize their personality. }\end{array}$ \\
\hline 7 & Moral models & $\begin{array}{l}\text { Teacher's characteristics have to be defined as a moral model. } \\
\text { The main pillars of professional responsibilities of a teacher have to be } \\
\text { clarified. }\end{array}$ \\
\hline 8 & $\begin{array}{l}\text { Expressing professional } \\
\text { responsibility }\end{array}$ & \multicolumn{2}{|c|}{} \\
\hline
\end{tabular}


Numerous studies (Ametrano, 2014; Amini Mashhadi, 2018; Azizi, 2010; Carr, 2005; Jafari, Abolghasemi, Ghahramani, \& Khorasani, 2017; Karimi, 2008; Majedi, Naderi, \& Seifnaraghi, 2019; Motallebi Fard, Nawe Ebrahim, \& Mohsen Zadeh, 2001; Warnick \& Silverman, 2011) revealed that most of the research work in the field focus on the teacher's professional ethics like ethics of teaching, professional capabilities of a teacher, academic qualifications and characteristics of a good teacher. However, this study aims to conceptualize teacher's professional ethics for all principles in his domain and offer solutions relevant for them.

The dominant theory in the field is that since the emphasis of ethics in existentialism is based on personal choice in objective circumstances, it is based on relativism (Holmes, 2003). Nevertheless, Buber with his belief in the existence of god, tries to give some space to absolute values in human's life. However, on the other hand, he strongly supports the idea of choice and human responsibility in the face of changed life conditions (Friedman, 2003). Thus, Ethical theory of Buber is of numerous strengths that could be utilized. The present study intends to extract guidelines for teacher's professional ethics in the domain of teacher- student interaction using ethical principles emphasized by Buber in the realm of humanhuman interaction.

\section{Material and Methods}

The present study is a qualitative research. The data required are collected through documentary method and the data collected are analyzed through Descriptive and interpretive analysis. In this regard, the researcher attempts to extract real concepts and themes from data (Mirzaei, 2016).

In order to present guidelines for each of the eight principles of teacher's professional ethics, inferential method is used. In this method, the researcher bases their work on a particular philosophical theory and provides logical consequences for education domain (Bagheri, Sajadieh, \& Tavasoli, 2010).

In the present study, considering principles and propositions of "normative ethics or theorems related to practical criteria of good and evil (Sharafi \& Imani, 2010)" in Buber's point of view, for each of the principles of teacher's professional ethics, criteria and indices are introduced.

\section{Results}

\section{Principles of Teacher's Professional Ethics in the Domain of Teacher- Student Interaction 1-Ultimate Criterion of Ethics: Establishing "I-Thou" Relation with "Otherness"}

According to Buber, two basic interactions could be found in the interaction humans have with the other; one is the real and desirable one also known as "I-Thou" relationship and the second one is the dominant relationship in the modern world which is the "I-It" relationship. Characteristic of I-Thou relationship is lack of existential integrity and the presence of human for the other occurring through experiencing the other in order to realize material purposes. In I-Thou relationship, an individual presents his/her self to the other without any intention to reach a goal and with existential integrity (M. Buber, 2016). Establishing an I-Thou relationship with the student must be the ultimate or original ethical criterion in teaching profession. Regarding this criterion, the teacher takes the desirable relationship with the student as the guarantee for realization of existential integrity. 


\section{2- Elaboration on Moral Vices and Virtues}

Table 3 elaborates on moral principles based on Buber's Point of view and the moral vices and virtues relevant to them.

Table 3. Moral Vices and Virtues in the Realm of Teacher-Student Interaction

\begin{tabular}{|l|l|}
\hline Ethical Principle & Moral Vice and Virtue \\
\hline $\begin{array}{l}\text { Unsuspensibility of morals in human } \\
\text { interactions }\end{array}$ & $\begin{array}{l}\text { Virtue: Deed based on the concept of unsuspensibility of moral element: the teacher } \\
\text { obliges himself to observe moral values when encountering students. He believes that in } \\
\text { an interaction with the student, ethical affair is not suspensible (Buber, 2013). }\end{array}$ \\
\cline { 2 - 2 } & $\begin{array}{l}\text { Vice: The deed based on possibility of suspension of moral element: The teacher divides } \\
\text { his life into public and private domains in which different moral values are permissible. } \\
\text { (Buber, 2014) }\end{array}$ \\
\hline
\end{tabular}

Reciprocity and inclusion in the relationship between human and other and the dialogue between them

Confirmation and making the other present

Virtue: Observing reciprocity and inclusion in interactions with students: for the teacher, it is not merely his ideas that matter. Students ideas are respected as well and the teacher begins a real conversation with his students (Buber, 1947).

Vice: Neglecting reciprocity and inclusion in interactions with students: For the teacher, it is only his ideas that matter. He neglects his students' ideas. He cannot address his students through a real dialogue.

Virtue: Trying to prepare students: The teacher does his best to prepare and confirm the student. In other words, the teacher understands the issues and the needs of the student. The teacher always confirms the student's originality even when the student disagrees with him (Buber, 1959).

Vice: Refusing to prepare students: The teacher does not prepare the student as an original individual and fails to understand and appreciate the student's issues and personal traits when encountering him (Buber, 1957).

Uniqueness of human relationship Virtue: Forming an exclusive relationship with the student: The teacher identifies the with the Other student as a unique creature that has to realize his existence in a unique way (Buber, 2016).

Vice: Refusing to form an exclusive relationship with the student: The teacher takes his students as "it" and takes a unique approach toward all of them.

Love for the Other

Virtue: Encountering the student with love: The teacher encounters the student in order to obey the command of God with a genuine love and out of kindness (Buber, 2013)

Vice: Encountering the student with hatred and cynicism: The teacher believing in a godless world, encounters students with arrogance and cynicism. This teacher is looking for realizing his lying self (Buber, 1959).

Relationship with the student from Virtue: Trying to see the student: Beside keeping his originality, the teacher confirms the side of the Other individuality of the student. In other words, he really sees the student (Buber, 1959).

Vice: Avoiding to see the student: When encountering the student, he rejects the student's originality and sometimes even abandons his originality as well (Buber, 1959).

Creating confidence in the relationship between human and the Other

Virtue: Trying to create confidence in the student: The teacher creates a sense of confidence between him and the student (Buber, 1959).

Vice: Distrust in the relationship between student and teacher: The teacher fears a comprehensive relationship with students with cynicism and distrust.

Realization of personality of Other and overcoming the Appearance appearance: The teacher collaborates in realization of personality of student (Buber, 1959) and in this regard, avoids superficiality (Buber, 1957).

Vice: Superficiality and refusing the responsibility to realize student's personality: The teacher refuses any responsibility regarding realization of personality of student and with superficiality accepts only the ones that matter to himself and help him reach his own goals (Buber, 1959).

Avoiding individuality and Virtue: Having a real encounter with the student: The teacher removes mental barriers of collectiveness individuality and collectiveness and interacts with the students as an individual (Smith, 2006).

Vice: Interacting the student based on individuality and collectiveness: Being influenced by collective values, the teacher avoids identifying the student as an individual. On the other hand, the teacher merely takes his own relationship as the basic and fails to properly encounter the student under the influence of individuality (Herberg, 1963). 


\section{3- How to Analyze and Encounter Objective Ethical Issues in Professional Activities:}

\section{A. First Criterion: Belief in Unsuspensibility of Ethics in Interactions with the Student}

Modern humans divide existence into two general and particular domains and oblige themselves to observe dual moral values. As a result of this moral duality, the teacher may commit a deed that is unacceptable in the case of himself or his acquaintances but he may permit it with his students ( $\underline{M}$. Buber, 2014). The teacher influenced by this moral duality may have proper behavior toward one student and may mistreat another student under racial, religious, gender and age considerations. This injustice however may provide the ground for numerous problems in teacher-student interactions.

\section{B. Second Criterion: Unique Encounter of a Student}

The teacher sometimes takes similar approaches to teach moral and academic concepts to students. Such teacher imagines all students as similar and prescribes similar prescriptions for all of them. However, the teacher with proper approach identifies originality of students as a desirable basis and tries to direct them toward salvation via identifying their particular talents.

\section{Third Criterion: Focusing on Cooperation in Professional Activities}

Innovation instinct is the motive for human to create in the world. Using this instinct, the student tries to build what he desires and reaches a personal achievement that has the potential to influence the world in an objective yet personal way; however, it fails to improve human relationships. In contrast, cooperation instinct helps the teacher interact with the student with all his heart (Martin Buber, 2003). The teacher, on the other hand, has to organize his professional affairs not on the innovation but on the cooperation instinct. One of the strategies that could help the teacher conduct the process of education based on cooperation instinct is using active teaching techniques. In active teaching techniques, the teacher and the student cooperatively participate in learning process, and the student takes the responsibility of building his body of knowledge.

\section{4- How to Resolve Moral Conflicts}

\section{A. First Criterion: Utilizing Inclusion Capability}

The root for many complex moral issues lies in the unresolved conflicts between student's freedom and teacher's authority. Like traditional approaches, modern educational trends have failed to balance principles of freedom and authority. Traditional views give total authority to the teacher and see no room for students' freedom. However, in modern approaches, the teacher has no authority against unlimited freedoms of the student (Murphy, 1988). In Buber's point of view or the approach of dialogue, there is no conflict between students' freedom and teachers' authority. In fact, for him, authority is the main requirement for realization of the student's freedom. Real freedom of the student is the ultimate goal of education and discipline is an effective strategy to reach this goal. For the teacher possessing educational discipline, freedom is the liberation of instinct to encounter which is the inherent capability of the student to have a dialogue with his own self, the teacher and the other students (Friedman, 2003).

\section{B. Second Criterion: Establishing a Relationship with Student by the Other}

The origin of many of moral conflicts in the classroom is the fact that the teacher plans all educational activities according to his personal view and neglects those of students. However, experience-based teaching students from the point of view of Other prevents the teacher from taking unilateral and personal actions in the classroom and base his plans according to inherent potentials of the students. 
The point worth mentioning about planed teaching according to experience of the student from the point of view of the Other; the teacher has to remember that since the student has not personally realized his personality and the teacher's activities have been inclusive, the student has to fully understand his teacher's approach (Friedman, 2003).

\section{Third Criterion: Gaining Student's Trust}

Students, nowadays, suffer disruption deep in their existence due to the ups and downs of the modern world, and this internal discord demonstrates itself as distrust in their relationship with their teachers. On the other hand, the teacher with a dominant sense of distrust to the surrounding world fails to communicate with their students. This distrust however is the origin of numerous moral conflicts in classroom context.

If the teacher presents him to the student, he will be able to create a sustainable trust in his student. This trust then will make the student an integral part of his teaching profession and will bring the teacher and the student closer through meeting the student's needs (Friedman, 2003).

\section{Forth Criterion: Taking the Responsibility to Realize Students' Personality}

Among all forces forming student's personality, the teacher is the most distinctive element for they have the power to form the student's personality (Martin Buber, 2003). When a child discovers the world with his liberated activities, he/she attempts to communicate with it as well (Friedman, 2003). Among all the people around, the student realizes his personality through communication and a dialogue with his teacher. Thus, students have to cooperate properly with their teachers and must feel the responsibility for this cooperation so that it creates a framework for teacher- student interaction and prevent any possible moral conflicts.

\section{5- Process of Changing and Correcting Behavior:}

\section{A. First Approach: Observing Inclusion when encountering the Student:}

The root for many undesirable behaviors in the context of education is organization of teacher's activities based on two modern and classic approaches toward education. The teacher influenced by classic approach attempts to take a sculptor's role and form the student according to the image he has in his mind. However, in the modern one, the teacher gives up against his students' will and tries to be a gardener who removes the barriers blocking free development of a child's internal potentials (Murphy, 1988). In these two approaches, the relationship between teacher and student forms in an incomplete manner. The proper replacement for them is the dialogue and inclusive interaction of the teacher and the student. The teacher's inclusion and dialogue based behavior gives the required position to both students and teachers.

\section{B. Second Approach: Avoiding Individuality and Collectiveness and Relieving by the Encounter} The teacher influenced by individuality possesses fake personality; while the one affected by collectiveness rejects any of the requests of his students against his party interests. The teacher making proper encounter with his students could relieve himself from bottlenecks of individuality and collectiveness. Such teacher is aware of the disorders suffered by his students in the modern world and obliges himself to make his students aware of their status, and they could try to evade their existential crises consciously (Martin Buber, 2003). 


\section{6- Purification of Soul and Elevation of Teacher's Personality:}

\section{A. First Index: Realization of True Perfection of Teacher's Personality through Real Encounter} with the Student

Perfection of human personality could not be realized merely through "I". However, it could not be realized without "I" as well. "I" needs "Thou" in the process of humanization (M. Buber, 2016). The teacher who has reached personality integrity will not think of domination or instrumental use of his students when encountering them. He does not treat them in a way that the development of their existential potentials are hindered. He appreciates presence of all students unconditionally (Friedman, 2003). This teacher tries to have a dialogue with his students over a moral issue. This dialogue will be based on Socratic questioning techniques (Murphy, 1988).

\section{B. Second Index: Teacher's Avoidance of Inception}

A teacher who is trying to reach an elevated personality should avoid inception or forcing his beliefs to his students. In the process of inception occurring unilaterally, the teacher puts his real personality away and encounters the student neglecting real circumstances of the student. However, inclusion capability is the opposing point of inception. In the light of inclusion, the teacher consciously develops his personality, and this helps him understand the presence of his student and his circumstances (Martin Buber, 2003).

\section{7- Teacher as a Moral Model}

\section{A. First Index: Using the Power of Love and Avoiding Superficiality}

An elite teacher puts arrogance and cynicism induced by the relationship of I-It with the world aside since God's content is of significance to him and builds his relationship with his students based on love and sympathy (M. Buber, 2013). The teacher has to purify his desires with humane motives and reach a higher degree of purification. In other words, he reaches an approach in which his responsibility is not interfering in his student's life; yet, he must do his best to realize his existence through utilizing his inherent potentials especially the power of love (Martin Buber, 2003).

\section{B. Second Index: Manifestation of a Great Character's Traits in Actions}

The model of teaching must manifest the image of a "Great Character" in actions and the teacher possessing a great character acts responsibly and uniquely when he faces a critical moment requiring something from him. The teacher could gain insight into the great character in order to overcome the problems existing in personality of students and their resilience in this regard (Martin Buber, 2003).

8- Elaborations on Professional Responsibility: Directing Professional Activities based on Realization of the Student

The ultimate goal of education in any society is to direct students toward perfection; the teacher is the most important element contributing to the realization of students. The teacher has to organize educational situations in a way that the ground for various interactions is provided for students. In the process of education, the teacher's actions should give a sense of commitment and purpose toward society and lead them to serve the humankind. The teacher creates a democratic atmosphere in the classroom due to the fact that he knows for sure that nurturing character in students could only be possible with real freedom. In order to realize the student, the teacher could provide opportunities in which the student experiences skills like self-assessment and self-contemplation. 


\section{Conclusion}

Considering Buber's ethical principles in interpersonal relationships, the present study aims to provide strategies for teacher's professional ethics in the domain of teacher-student interactions. In the domain of teacher's professional ethics, Buber's concept of positive thinking also known as "moral virtues" is emphasized and utilized. In fact, moral virtues for Buber are ethical components of a desirable human relationship which could be taken as ethical responsibilities of the teacher. In a world in which educational systems and the curricula compiled by them encourages non-personalization and selfalienation in teacher-student interactions, teacher's actions based on moral virtues of Buber could facilitate building identity for students.

Besides, with reuniting capabilities of the final or original moral criterion which is the establishment of I-Thou relationship with the other (the student) in this study; the main direction of other teacher's professional ethics is determined properly. On the other hand, these principles have to contribute to the realization of this criterion. It is worth mentioning that Buber's conceptualization in teacher's professional ethics possesses another important strength. For Buber, the real position and weight is given to both teacher and student so that reflection of establishment of I-Thou relationship of Buber in educational procedures lead to significant decrease among educational principles. In Buber's point of view, humane discipline and authority of the teacher is a major requirement for realization of real freedom of the student. In other words, freedom for a student is his cooperation with the teacher and his classmates (Principles of freedom and discipline). On the other hand, Buber believes that purposeful activities of the student guiding him toward a more desirable life in the future, play a constructive role (Principles of perfection and activity). Finally, Buber believes that a constructive educational group will only get the point if the students join the group and participate in it freely while preserving their independence (Principles of individuality and society).

Conflict of interest: The authors state no conflict of interest in the study.

Financial sponsor: The authors acknowledge that they have not received any financial support for all stages of the study, writing and publication of the paper.

\section{References}

Ametrano, I. M. (2014). Teaching ethical decision making: Helping students reconcile personal and professional values. Journal of Counseling \& Development, 92(2), 154-161.

Amini Mashhadi, S. (2018). Explaining the professional ethics of teaching: a reflection on the views of David Carr and Allameh Tabatabaei. (Ph.D Thesis), Ferdowsi University, Mashhad.

Azizi, N. (2010). Professional ethics in higher education: A reflection on strategies to improve ethical standards in academic education. Strategy for Culture, 3(8), 173-202.

Bagheri, K., Sajadieh, N., \& Tavasoli, T. (2010). Research approaches and methods in philosophy of education. Tehran: Institute of cultural and social studies.

Buber, M. (2003). Between man and man: Routledge. 
Buber, M. (2013). Eclips of God (A. Kashef. \& A. Sohrab, Trans.). Tehran: Forouzane-rouz. Buber, M. (2014). On Judaism (A. F. Vadeghani, Trans.). Qom: Adyan.

Buber, M. (2016). I and Thou (A. Sohrab. \& E. Attarodi, Trans.). Tehran: Forouzane-rouz.

Carr, D. (2005). Professionalism and ethics in teaching: Routledge.

Faramarz Gharamaleki, A. (2010). An introduction to professional ethics. Tehran: Saramad.

Friedman, M. S. (2003). Martin Buber: The life of dialogue: Routledge.

Gutek, G. L. (1997). Philosophical and ideological perspectives on education: ERIC.

Haydon, G. (1996). Should teachers have their own professional ethics? Journal of Philosophy of Education, 30(2), 301-306.

Holmes, R. L. (2003). Fundamentals of philosophy of ethics. Translated by Massoud Alia. Tehran: Phoenix Publishing.[In Persian].

Jafari, H., Abolghasemi, M., Ghahramani, M., \& Khorasani, A. (2017). Organizational and contextual factors of professional development of elementary teachers in special schools. Journal of School Administration, 5(1), 73-92.

Karimi, F. (2008). Studying professional qualifications of primary teachers. Quarterly Journal of Educational Leadership and Administration, 2(4), 151-166.

Macquarie, J. (1998). Existential philosophy. Translated by Mohammad Saeed HanaeiKashani. Tehran: Hermes.

Majedi, P., Naderi, E., \& Seifnaraghi, M. (2019). Designing a model of teacher competencies in accordance with global characteristics and validating it from the viewpoint of educational experts and exemplary teachers of schools in Tehran. Journal of School Administration, 7(1), 84-104.

Mirzaei, K. (2016). Research, researcher and writing research (Vol. 1). Tehran: Fozhan.

Motallebi Fard, A., Nawe Ebrahim, A., \& Mohsen Zadeh, F. (2001). Investigation and Identification of professional and ethical markers in instruction and teaching from the point of view of master students: A qualitative study. International Journal of Ethics and Society, 6(2), 1-8.

Murphy, D. (1988). Martin Buber's philosophy of education. Dublin: Irish Academic Press.

Seif, S. M. (2006). A reflection on Martin Buber's philosophy of dialogue. Journal of Nameh-Ye-Mofid, 2(2), 43-58.

Sharafi, M., \& Imani, M. (2010). Review and critique of ethics in the thought of Martin Buber. Quarterly Journal of New Thoughts on Education, 6(2), 9-52.

Warnick, B. R., \& Silverman, S. K. (2011). A framework for professional ethics courses in teacher education. Journal of Teacher Education, 62(3), 273-285. 